\title{
Patient Satisfaction Reviewed from Dimension Reliability in Community Health Center
}

\author{
Herbert Wau*, Dewinta Isabora G.Purba** \\ *M Author Correspondence: Dewintaigpurba@gmail.com \\ *Universitas Prima Indonesia, Jl. Sekip Jl. Sikambing No.Simpang, Sei Putih Tim. I, Kec. Medan Petisah, Medan City, Indonesia \\ **Universitas Prima Indonesia, Jl. Sekip Jl. Sikambing No.Simpang, Sei Putih Tim. I, Kec. Medan Petisah, Medan City, Indonesia

\begin{tabular}{l}
\hline I N D E X I N G \\
\hline Keywords: \\
Reliability Dimension; \\
Patient Satisfaction; \\
Community Community \\
Health Center;
\end{tabular}

\begin{abstract}
A B S T R AC T
Patient satisfaction in health care is a key indicator of the success of health service delivery. Reliability is the ability to provide the promised service immediately, accurately and satisfactorily. If the reliability dimension is not implemented properly it will cause problems so that it can affect patient satisfaction. The purpose of this study was to determine the effect of the reliability dimension on patient satisfaction at the Padang Bulan Community Health Center in Medan. Data collection was carried out by in-depth interviews (in-depth interviews). Data analysis was performed descriptively and presented in narrative form. The sample in this study were 4 patients and 2 health workers with a total of 6 people. The results showed that there was an influence on the speed of health checks, accuracy of service schedules, and health workers provided clear information on patient satisfaction
\end{abstract} \\ at the Padang Bulan Community Health Center in Medan.
}

Kata kunci:

Dimensi Reliability;

Kepuasan Pasien;

Puskesmas;
Kepuasan pasien dalam pelayanan kesehatan merupakan indikator utama keberhasilan pemberian pelayanan kesehatan. Kehandalan (reliability) merupakan kemampuan memberikan pelayanan yang dijanjikan dengan segera, akurat dan memuaskan. Jika dimensi reliability ini tidak diterapkan dengan baik maka akan menimbulkan masalah sehingga dapat berpengaruh terhadap kepuasan pasien. Tujuan penelitian ini untuk mengetahui pengaruh dimensi reliability terhadap kepuasan pasien di Community Community Health Center Padang Bulan Medan. Pengumpulan data dilakukan dengan wawancara mendalam (indepth inetrview). Analisis data dilakukan secara deskriptif dan disajikan dalam bentuk narasi. Sampel dalam penelitian ini adalah 4 pasien dan 2 petugas kesehatan dengan total jumlah 6 orang. Hasil penelitian menunjukkan terdapat pengaruh kecepatan pemeriksaan kesehatan, ketepatan jadwal pelayanan, dan petugas kesehatan memberikan informasi yang jelas terhadap kepuasan pasien di Community Community Health Center Padang Bulan Medan.

(C) 2019 JMMR. All rights reserved

\section{INTRODUCTION}

Health services are services that can be assessed or felt through a performance. The need for satisfying health services influences people to choose health facilities where the community wants the best service for themselves. Meanwhile, according to Mubarak health service is an effort that is carried out independently or together in an organization to improve health, prevent and treat individual, family, group, and community diseases. ${ }^{2}$

In creating national development, quality health services are needed for the community. Improving the quality and quantity of existing health services from health institutions can create a lifestyle of people who care, understand and respond to health problems that exist in the surrounding environment. One form of service quality is medical action taken as soon as possible in handling patients, while ensuring patient safety. ${ }^{-}$
Quality health services one aspect of health care is an important factor in achieving patient satisfaction. ${ }^{5}$

Patient satisfaction is a key indicator of the success of health service delivery. The position of the Community Community Health Center as the spearhead in the health service system. Because the Community Community Health Center is the first health institution dealing directly with patients. The Community Community Health Center has responsibility for the work area, which is a sub-district. Community Community Health Center has a vision of achieving a healthy sub-district. Healthy sub-districts include 4 main indicators, namely healthy relationships, healthy behavior, quality health service coverage, and the health status of the population. ${ }^{-}$

Patient satisfaction is a patient feeling that arises as a result of the performance of health services he obtained after the patient compared it with what he expected. ${ }^{7}$ Patient or participant insurance satisfaction is one factor that can be 
used as a reference in determining the success of a service program.

This means that the good quality of a service is not based on the perception of service providers, but based on the perception of consumers because consumers who enjoy the services provided by the company. ${ }^{-}$

The services provided by health services, especially Community Community Health Center, must be quality and meet five main quality dimensions, namely: tangibles (physical facilities), reliability, responsiveness, assurance and empathy to create patient satisfaction. ${ }^{3}$

Reliability is the ability to provide the promised service immediately, accurately and satisfactorily. If the reliability dimension is not implemented properly it will cause problems so that it can affect patient satisfaction. ${ }^{9}$

In the study of Fitriyanah, which aims to find out the level of general patient satisfaction about the quality of nursing care inpatient units in class 3 at RSUD dr. H Soewondo, Kendal. ${ }^{4}$ The results showed that the reliability dimension in general patients was $58.8 \%$ satisfied (20) and $35.3 \%$ dissatisfied (12). On the guarantee (assurance) of general patients expressed satisfaction as much as $55.9 \%$ (19) and not satisfied as much as $38.2 \%$ (13). Physical evidence shows that general patients expressed satisfaction as much as $64.7 \%$ (22) and dissatisfaction as much as $32.4 \%$ (11). Empathy (emphaty) shows that general patient respondents expressed satisfaction as much as $61.8 \%$ (21) and not satisfied as much as $35.3 \%$ (12). Response (responsiveness) in general patients expressed dissatisfaction as much as $61.8 \%$ (21) and respondents who expressed satisfaction as much as $38.2 \%$ (14).

While Sari's study, which aims to analyze whether there are differences in the level of satisfaction of BPJS patients with general patients in RSUD dr. Soediran Mangun Sumarso, Wonogiri. $\stackrel{10}{-}$ The results showed that there was a significant difference between the level of satisfaction of BPJS patients and general patients, with the results of general patient satisfaction levels better than BPJS patients with a difference of both of them at $39.51 \%$. The average level of general patient satisfaction was 106.14 while that for BPJS patients was 66.62 .

When the researcher conducted an initial survey at the Padang Bulan Community Health Center, the researcher talked with a visitor.

When researchers ask: have you received services? The answer: I was waiting for the doctor to examine me, but the doctor was not there, until twice the staff at the Community Community
Health Center welcomed me to wait for the doctor, I felt the service at this Community Community Health Center needed to be reported.

Judging from the complaints of visitors, the lack of reliability dimension (reliability) in Community Community Health Center Padang Bulan. Dimensions of reliability (reliability) must be in accordance with customer expectations, this is meant by timely performance, service without errors, sympathetic and satisfying attitude.

Data from patient visits at the Padang Bulan Community Health Center in October 2018 recorded 3,111 visits, November 2018 recorded 2,778 visits, and December 2018 recorded 2,495 visits. From these data it is proven that there is a decrease in the number of visitors in 2018. To see patient satisfaction at the Padang Bulan Community Health Center managed by the government, related to the description above, the researcher wants to explore further on "The Effect of the Reliability Dimension on Patient Satisfaction at the Padang Bulan Community Health Center in Medan".

\section{RESEARCH METHOD}

This type of research conducted in this study uses qualitative. The research variables in this study consisted of independent variables namely the speed of examination (diagnosis), the accuracy of the service schedule and the clerk gave clear information, while the dependent variable was patient satisfaction.

Samples were obtained using the simple random sampling method because the elements of the population are homogeneous. The sample in this study were 4 patients and 2 health workers who were at the Community Health Center Padang Bulan with a total of 6 people. Data collection is done by indepth interview method and direct observation of informants.

The data processing method uses triangulation of methods and source triangulation. Primary data were obtained from interviews. Secondary data were obtained from Community Health Center Padang Bulan. Data processing methods were analyzed manually, namely by writing down the results of research in the form of in-depth interview tables.

\section{RESULTS AND DISCUSSION}

The location of this research is in Padang Bulan Community Health Center, address on Jl. Jamin Ginting No.31, Padang Bulan, Kec. Medan Baru, Kota Medan, North Sumatra 20157. The working area of the Padang 
Bulan Community Health Center covers 6 sub-districts in the Medan Baru sub-district.

At the data collection stage, it was conducted for 2 days on 18 July 2019 - 19 July 2019. Then the research began to be carried out by interviewing informants in depth with a voice recording device. The research was carried out during the research day from 08.00 WIB - 15.00 WIB. Before the interview began, the researcher gave an explanation of the purpose of the interview and gave a statement of approval by the informant. On July 19, 2019, all informants had finished being interviewed.

\section{Speed of Health Checks on the Reliability Dimension}

From the results of the study, the statement of the health worker informant about the speed of examination (diagnosis) provided by health workers to patients is good. It can be concluded that the Community Community Health Center staff have provided satisfactory services to patients specifically for the speed of examination (diagnosis).

While the statement of patient informants about the speed of examination (diagnosis) provided by health workers to patient satisfaction are good. The researcher also observed firsthand how the speed of the officers conducting the examination and treatment of patients was categorized as good, because it was in accordance with the patient's statement.

The speed of health checks on the reliability dimension is a tool to measure the reliability of the Community Community Health Center to its customers. The aim is to measure the speed of health checks at a Community Health Center to improve the quality of services available at the Community Health Center so that it can increase patient satisfaction.

The length of health services that require a long examination process will cause patients to be less motivated to take advantage of these health services, especially if during the waiting time, health workers do not interact with patients who are waiting. With these conditions, patients can simply consider health services in these places less quality and feel less satisfied. $\stackrel{11}{-}$

The dimension of reliability in the speed of health examination is shown by how long the doctor takes the examination and treatment to the patient. This dimension states the consistency and reliability of the health service provider.

The will or desire of patients and the community can be known through patient satisfaction surveys. Experience has proven that economic transformation will inevitably change people's wants and needs for health services. Patient satisfaction surveys are important and need to be carried out in conjunction with other dimensions of quality of health services. $^{\text {? }}$

Based on the table 1. results of the study the speed of health checks provided by health workers to patients is good. This is consistent with the results of interviews with patient informants, namely:

\section{Table 1. Interview result}

\begin{tabular}{|c|c|c|}
\hline No & Informant & Interview result \\
\hline 1 & $\begin{array}{l}\text { Patient } \\
\text { informant } 1\end{array}$ & $\begin{array}{l}\text { "I think the inspection service is } \\
\text { good. The doctor in my opinion is } \\
\text { serious about checking health and } \\
\text { the services provided specifically for } \\
\text { me are good and satisfying. }\end{array}$ \\
\hline 2 & $\begin{array}{l}\text { Patient } \\
\text { informant } 3\end{array}$ & $\begin{array}{l}\text { "The speed of the health check given } \\
\text { to me is fast. The doctor who } \\
\text { examined me was serious. Yes, the } \\
\text { term was in accordance with the } \\
\text { results of the diagnosis, the speed of } \\
\text { the service provided specifically for } \\
\text { me was good. }\end{array}$ \\
\hline
\end{tabular}

Based on the table 2. results of the study the speed of health checks provided by health workers to patients is good. This is in accordance with the results of interviews with health personnel informants, namely:

Table 2. Interview result

\begin{tabular}{lll}
\hline No & Informant & \multicolumn{1}{c}{ Interview result } \\
\hline 1 & Health & "Usually doctors do examinations \\
& workers 1 & and treatment to patients for about \\
& & 15 minutes. The length of time the \\
& & doctor examines BPJS patients and \\
& the general public is all the same ". \\
& Health & "Here about 10 minutes so the deck \\
& workers 2 & examines patients. There has not \\
& & been a patient both BPS and \\
& & time the doctor examined ".
\end{tabular}

On observations made by researchers, that the average health examination process ranges from 5-10 minutes for general examinations, but for dental poly the duration is $5-15$ minutes. This is in accordance with the statements of patient informants and health workers.

According to $\frac{13}{}$, satisfaction is a feeling of pleasure or disappointment someone who appears after comparing the perception or impression of the performance or results of a product or expectations. Satisfaction is a function of perception or impression of performance and expectations. There are three levels of satisfaction, namely the value of performance is below expectations, and patients are not 
satisfied. If performance meets expectations, the patient is satisfied.

\section{Accuracy of Service Schedule in the Reliability Dimension}

From the results of the study, the statement of health personnel informants can be seen that the accuracy of the service schedule at the Padang Bulan Community Health Center is not good. Evidenced by the statement that there are still health workers who come not on time and go home during working hours which causes patients to complain.

While the patient's informant's statement can be seen that the accuracy of the service schedule at the Padang Bulan Community Health Center is not good. From the results of the statement, the majority of patients said the lack of accuracy of the schedule of services available at the Community Health Center. It was proven by the statement that the health worker, namely the doctor, went home while working hours so that the patient could not seek treatment.

The accuracy of the service schedule on the reliability dimension is health services carried out in the right time and manner, by the right service provider, doctor's visit, speed of service registration and performance of officers from the accuracy of the service schedule in providing services to patients so that patients feel satisfied with the fulfillment of their needs. ${ }^{14}$

The availability of service timeliness can reflect the effectiveness of Community Community Health Center work. This is in accordance with the opinion that says that one of the criteria that can be used to measure the effectiveness of the work of the organization is the time factor, where the time factor here means the timeliness and speed of time of service provided by service providers. ${ }^{11}$

Based on table 3. patient satisfaction surveys through interviews about the accuracy of the promised service schedule as follows:

Table 3. Interview result

\begin{tabular}{|c|c|c|}
\hline No & Informant & Interview result \\
\hline 1 & $\begin{array}{l}\text { Patient } \\
\text { informant } 2\end{array}$ & $\begin{array}{l}\text { "The accuracy of the schedule is not } \\
\text { good. Sometimes when I want } \\
\text { treatment at } 12 \text { noon the Community } \\
\text { Community Health Center is closed } \\
\text { and the staff said the doctor has } \\
\text { returned. If he sees today he is still } \\
\text { open because the doctor is still there } \\
" .\end{array}$ \\
\hline 2 & $\begin{array}{l}\text { Patient } \\
\text { informant } 4\end{array}$ & $\begin{array}{l}\text { "In my opinion the accuracy of the } \\
\text { service schedule is not good. } \\
\text { Sometimes I want to go for treatment } \\
\text { at } 9 \text { in the morning the doctor has not }\end{array}$ \\
\hline
\end{tabular}

\begin{tabular}{ll}
\hline No $\quad$ Informant & \multicolumn{1}{c}{ Interview result } \\
\hline & $\begin{array}{l}\text { arrived yet, but I want to go for } \\
\text { treatment at noon the doctor has } \\
\text { returned, said the employee ". }\end{array}$ \\
\hline
\end{tabular}

In the statement above both the majority of patients feel less satisfied with the services provided, thus affecting a quality of service. The quality of health services is good if the Community Community Health Center provides services that are as expected by the patient for the patient's needs. While poor quality if the patient receives health services that are less in accordance with the needs and expectations of patients.

This is table 4. consistent with the statement of the health worker informant, namely:

\section{Table 4. Interview result}

\begin{tabular}{|c|c|c|}
\hline No & Informant & Interview result \\
\hline 1 & $\begin{array}{l}\text { Health } \\
\text { workers } 1\end{array}$ & $\begin{array}{l}\text { "There are health workers who are } \\
\text { on time and some are late. There is } \\
\text { also a la who returned home not in } \\
\text { time because there were other needs, } \\
\text { both doctors and other employees" }\end{array}$ \\
\hline 2 & $\begin{array}{l}\text { Health } \\
\text { workers } 2\end{array}$ & $\begin{array}{l}\text { "It depends on the health staff on } \\
\text { deck, some arrive on time, others } \\
\text { don't arrive on time. Here there are } \\
\text { health workers who go home not yet } \\
\text { in time namely the doctor, so here the } \\
\text { patient is in the middle of an upset, } \\
\text { the patient comes noon, while the } \\
\text { rules are from } 8 \text { am to } 6 \mathrm{pm} \text { " }\end{array}$ \\
\hline
\end{tabular}

Observations made by researchers at the Community Health Center, there are still health workers who come late and go home or go to work, the speed of registration services is also relatively slow so that the queue becomes long and patients wait a long time for treatment. When conducting research, researchers also get patients who complain because of the length of service at the Community Health Center.

For quality of care to be successful, health services must be carried out in the right time and manner. In a health service must be able to meet the needs felt by the community and be organized in a manner that is polite and polite, timely, responsive and able to cure complaints and prevent the development or spread of disease..$^{12}$

Timeliness is an activity to maintain the quality of service. In order to be successful, health services must be carried out in the right time and manner, by the right 
service provider, and using the right equipment and medicine, and with cost-efficient (right)..$^{15}$

If the services obtained by patients are as expected, patients get satisfaction so patients will come back to get better services. $\frac{16}{}$

According to ${ }^{9}$ reliability is the ability to provide the promised service immediately, accurately and satisfactorily, as well as the ability to provide the service promised.

Therefore, each Community Community Health Center must try to position itself as best as possible in the eyes of patients / customers so that they can be trusted to meet their needs in the health sector. ${ }^{17}$

\section{Health Officers Give Clear Information on the Reliability Dimension}

From the results of the study, the statement of health personnel informants can be seen health workers provide information that is clearly categorized very well. Health workers have complied with the regulations in force at the Community Community Health Center to serve patients in a friendly manner in accordance with the applicable standards at the Community Community Health Center.

While the patient informant's statement can be seen that the patient's response to the health worker providing clear information is very good. Patients stated that health workers were friendly in providing unclear information as well as information about illnesses that the patient suffered.

The reliability dimension relates to the willingness and ability of health workers to help patients and respond to their requests, as well as informing when services will be provided. Community Health Centers are said to have reliability if health workers are always ready at any time to help patients provide clear information to patients, a convoluted service system and quick response to patient complaints.

This dimension of information is very important at the level of Community Health Centers and hospitals. Information relating to all types of news and health services information received by patients. The clearer and better the information received by the patient, the more satisfied the patient is with the health services provided..$^{12}$

The success of the delivery of information by health workers to patients is influenced by the communication created by both parties. Health workers as communicators must be able to communicate well with patients, while patients as news recipients are expected to receive information well. $\frac{18}{}$
Based on patient satisfaction surveys through interviews about the clarity of information provision as follows:

\section{Table 5. Interview result}

\begin{tabular}{lll}
\hline No & Informant & \multicolumn{1}{c}{ Interview result } \\
\hline 1 & Patient & "The patient admission procedure is \\
& informant 2 & good. The officer was also willing to \\
& & explain kindly again if I did not \\
& understand and the doctor explained \\
& my illness clearly. I was satisfied \\
& with the service ". \\
& Patient & "The procedure for admitting \\
& informant 4 & patients is rather slow because there \\
& & are also many patients, but the \\
& officers are friendly if I do not \\
& understand the procedure. The \\
& doctor also clearly explained about \\
& my illness. I am quite satisfied with \\
& the service.
\end{tabular}

Based on the results of the study the attitude of friendly and polite health workers in handling patient complaints. The attitude of friendly and kind officers in providing services can be a determinant of a patient's recovery, on the contrary the attitude of the officer who is rude and indifferent can reduce patient satisfaction with the service he receives.

This is consistent with the results of interviews with health personnel informants, namely:

Table 6. Interview result

\begin{tabular}{|c|c|c|}
\hline No & Informant & Interview result \\
\hline 1 & $\begin{array}{l}\text { Health workers } \\
1\end{array}$ & $\begin{array}{l}\text { "For patients who complain of lack of } \\
\text { information, they are well informed or } \\
\text { treat patients with courtesy and } \\
\text { friendliness. The doctor explains the } \\
\text { patient's disease clearly and must be } \\
\text { detailed" }\end{array}$ \\
\hline 2 & $\begin{array}{l}\text { Health workers } \\
2\end{array}$ & $\begin{array}{l}\text { "To deal with uninformed patients I } \\
\text { will answer them politely friendly, } \\
\text { there is no way I can answer with } \\
\text { anger either, so what patients want us } \\
\text { to educate clearly. The doctor also } \\
\text { explained the patient's illness clearly" }\end{array}$ \\
\hline
\end{tabular}

Observations made by researchers at the Community Health Center that health workers are friendly in explaining information to patients. When there are patients who complain, health workers also conduct education in a polite manner so that patients are calm and patient to wait for the queue of medical examinations.

According to ${ }^{19}$, politeness and friendliness in service especially direct interaction, and comfort in obtaining services related to location, space where services, ease of 
reaching out, availability of information are attributes in the quality of service.

Health services are seen as good because the officers are friendly, friendly, patient and communicative. Conversely, if the service is considered poor, it is because the officers are rude and speak disrespectfully. ${ }^{20}$

Patient satisfaction can be assessed based on the patient's interpretation of the services received that are in accordance with their expectations such as the completeness of facilities and infrastructure, hospitality and courtesy of officers in providing services and the skills of officers when providing services. ${ }^{1}$

\section{CONCLUSION}

From the results of research conducted at the Padang Bulan Community Health Center, it can be concluded that the reliability dimension includes three factors, namely the speed of health checks, the accuracy of the service schedule, and health workers providing clear information that is strongly related to patient satisfaction at the Padang Bulan Community Health Center in Medan. Variable accuracy of service schedules for patient satisfaction is categorized as unsatisfactory, this is due to the fact that there are still health workers who arrive not on time and go home during working hours. Therefore, health workers in the Padang Bulan Medan Community Health Center must further improve discipline such as arriving on time and returning at the designated time in order to increase patient satisfaction so as to improve the quality of services available at the Community Health Center to be better.

\section{REFERENCE}

1. Suryati, B. W. Dan V. T. I. Faktor-Faktor Yang Berhubungan Dengan Kepuasan Pasien BPJS Terhadap Pelayanan Rawat Jalan Di Rumah Sakit Panti Wilasa Citarum Semarang. 5, (2017).

2. Mubarak, W. I. Ilmu Kesehatan Masyarakat. (Salemba Medika, 2009).

3. Lestari Dkk, D. R. M. Perbedaan Antara Kualitas Pelayanan Kesehatan Umum Dan Kepemilikan Kis Pada Lansia Di Community Community Health Center Dau Malang. 2, (2017).

4. Fitriyanah Dkk, E. Perbedaan Tingkat Kepuasan Pasien Bpjs Dan Pasien Umum Tentang Mutu Pelayanan Keperawatan Unit Rawat Inap Kelas 3 Rsud Dr. H Soewondo Kendal. 1-18 (2017).

5. Murtiana, E. Hubungan Mutu Pelayanan Kesehatan Dengan Kepuasan Pasien Bpjs Di Rsud Kota Kendari Tahun 2016. (2016).
6. Handayani, S. The Level Of Patient Satisfaction With Health Services In Baturetno Community Health Centers. 14, (2016).

7. Pohan, S. I. Jaminan Mutu Pelayanan Kesehatan. (ECG, 2007).

8. Pertiwi, A. A. N. Analisis Perbedaan Kualitas Pelayanan Pada Pasien Bpjs Dan Pasien Umum Terhadap Kepuasan Pasien Di Rawat Jalan Rsud Kota Surakarta. (2016).

9. Jacobis, R. Faktor-Faktor Kualitas Pelayanan Pengaruhnya Terhadap Kepuasan Pasien Rawat Inap Peserta Jamkesmas Di Blu Rsup Prof.Dr. R.D. Kandou Manado. 1, 619-629 (2013).

10. Sari, P. A. Perbedaan Tingkat Kepuasan Pasien Bpjs Dengan Pasien Umum Di Rsud Dr. Soediran Mangun Sumarso Wonogiri. (2015).

11. Mane, D. Persepsi Masyarakat Terhadap Pelayanan Community Community Health Center (Studi Di Desa Nggele Kecamatan Taliabu Barat Laut Kabupaten Pulau Taliabu Provinsi Maluku Utara). 3, 325-335 (2018).

12. Pohan, S. I. Jaminan Mutu Pelayanan Kesehatan, Dasar-Dasar Pengertian Dan Terapan. (ECG, 2006).

13. Kotler, P. Dasar-Dasar Pemasaran. (PT. Indeks, 2007).

14. Efendi, Arifin, D. Hubungan Mutu Pelayanan Kesehatan Dengan Kepuasan Pasien Rawat Jalan Di Community Community Health Center Aeng Towa Kabupaten Takalar. 1-12 (2013).

15. Setiawan, R. D. Kualitas Pelayanan Community Community Health Center Karangdowo Kabupaten Klaten Kepada Pasien Jamkesmas Skripsi. (2010).

16. Annisa, Z. O. Perbedaan Tingkat Kepuasan Pasien Bpjs Dan Non Bpjs Pada Mutu Pelayanan Pendaftaran Rumah Sakit Pusat Angkatan Udara Dr. S. Hardjolukito Bantul. (2016).

17. Kuntoro, W. \& Istiono, W. Kepuasan Pasien Terhadap Kualitas Pelayanan Di Tempat Pendaftaran Pasien Rawat Jalan Community Community Health Center Kretek Bantul Yogyakarta. 2, (2017).

18. Darwono, A. Analisis Faktor-Faktor Kejelasan Informasi Medis Yang Diterima Oleh Pasien Pra Operasi Katarak Di Rumah Sakit Umum William Booth Semarang Tahun 2006. (2006).

19. Utami, W. Pengaruh Dimensi Kualitas Pelayanan Community Community Health Center S . Parman Banjarmasin Terhadap Kepuasan Pasien Dalam Memperoleh Pelayanan Kesehatan. 65-90 (2012).

20. Nursalam. Manajemen Keperawatan Aplikasi Dalam 
Praktik Keperawatan Profesional. (Salemba Medika, 2007). 